\title{
Zaburzenia zachowania i emocji w zespole Tourette'a
}

\author{
Behavioral and emotional disorders in Tourette syndrome
}

\author{
Aleksandra Dąbrowska (iD), Barbara Steinborn (iD) \\ Katedra i Klinika Neurologii Wieku Rozwojowego, Uniwersytet Medyczny im. K. Marcinkowskiego w Poznaniu \\ DOI:10.20966/chn.2019.57.450
}

\section{STRESZCZENIE}

Zespół Tourette'a (TS) jest zaburzeniem neurorozwojowym, które charakteryzuje się współwystępowaniem tików motorycznych i wokalnych. Zaburzenie zwykle ma swój początek w dzieciństwie, a jego objawy mogą utrzymywać się również w okresie dorosłości. U większości pacjentów z TS rozpoznaje się zaburzenia współwystępujące, które mogą w znaczącym stopniu wpływać na obraz kliniczny choroby. W artykule przedstawiono zaburzenia zachowania i emocji, które są diagnozowane u osób z TS najczęściej, a mianowicie: zespół nadpobudliwości psychoruchowej z deficytem uwagi (ADHD), zaburzenia obsesyjno-kompulsyjne (OCD), depresję, zaburzenia zachowania (CD) oraz zachowania samookaleczające (SIB).

Słowa kluczowe: zespół Tourette'a, zaburzenia zachowania, zaburzenia emocji

\section{ABSTRACT}

Tourette syndrome (TS) is a neurodevelopmental disorder characterized by the co-occurrence of motor and vocal tics. TS usually begins in childhood and its symptoms may also persist into adulthood. Most patients with TS are diagnosed with comorbidities that can significantly affect the clinical picture of the disease. The article presents behavioral and emotional disorders that are most often diagnosed in people with TS, namely: attention deficit hyperactivity disorder (ADHD), obsessive-compulsive disorder (OCD), depression, conduct disorder (CD) and self-injurious behaviour (SIB).

Key words: Tourette syndrome, behavioral disorders, emotional disorders

\section{WPROWADZENIE}

W 1885 roku opublikowano raport na temat grupy pacjentów, w której zaobserwowano wspólne objawy, polegające na nagłych ruchach mimowolnych, nadmiernej pobudliwości oraz nietypowych wokalizacjach. Twórca raportu, francuski neurolog Gilles de la Tourette, zawarł w nim informacje uwzględniające cechy kliniczne, przebieg, a także spekulacje dotyczące genetycznego podłoża zaburzenia i jego początku w okresie dzieciństwa. Ten dokładny opis stanowił podstawę zespołu obecnego we współczesnych klasyfikacjach chorób, początkowo uznawanego za zjawisko niezwykłe i egzotyczne. Na przestrzeni lat, w wyniku badań neurobiologicznych i psychiatrycznych, konceptualizacja zespołu Tourette'a ulegała licznym zmianom [1].

\section{DEFINICJA I ETIOLOGIA ZESPOŁU TOURETTE'A (TS)}

W Międzynarodowej Klasyfikacji Chorób ICD-10 zespół Tourette'a (TS) definiuje się jako postać tików, charakteryzująca się współwystępowaniem tików motorycznych z jednym lub wieloma tikami wokalnymi, które nie muszą jednak występować jednocześnie. Zaburzenie ma swój początek w dzieciństwie, bądź okresie młodzieńczym i nierzadko utrzymuje się w okresie dorosłości. W przebiegu zespołu Tourette’a tiki ruchowe występują zwykle wcześniej, niż tiki głosowe. Tiki wokalne pojawiają się gwałtownie, często w liczbie mnogiej i mogą przyjmować postać wokalizacji, odkasływania, chrząkania oraz wulgaryzmów. Z wymienionymi objawami współwystępują czasami zachowania polegające na naśladowaniu gestów innych osób, w tym kopropraksja. Zarówno tiki motorycz- ne, jak i wokalne nasilają się w sytuacjach stresowych oraz ulegają wygaszeniu podczas snu. Osoby z zespołem Tourette'a są w stanie przez krótki okres czasu powstrzymywać objawy [2].

Według danych, mężczyźni chorują częściej, niż kobiety - stosunek płci męskiej do żeńskiej wynosi 4:1, a średni wiek zachorowania to 6,4 lat. W przebiegu zespołu Tourette'a tiki ustępują w okresie dorosłości u około $50 \%$ pacjentów, u 40-45\% występują rzadziej, a u 5-10\% pozostają bez zmian [3]. TS dotyka przynajmniej 1\% całej populacji. W przypadku dzieci, liczba zachorowań na 1000 uczniów wynosi od 1 do 10. Według badań z 2000 roku, występowanie TS w populacji uczniów polskich szacuje się na $0,43-3,8 \%[4,5]$.

Etiologia zespołu Tourette'a nie jest do końca znana. Istnieją hipotezy, które biorą pod uwagę przyczyny genetyczne, mówiące o dziedziczeniu autosomalnym dominującym. Inne zaznaczają występowanie nieprawidłowości w zakresie neuroprzekaźników (głównie dopaminy, serotoniny i noradrenaliny). W tym przypadku uważa się, że u osób z TS dochodzi do nadwrażliwości receptorów dopaminowych, a także obniżonego działania serotoniny i noradrenaliny. Trzecia hipoteza wskazuje na nieprawidłowości w obrębie jąder podstawy oraz pętli korowo-prążkowo-wzgórzowej. W patogenezie zaburzenia zaznacza się także wpływ powtarzających się infekcji paciorkowcowych oraz problemów przed- i okołoporodowych, takich jak: wymioty w pierwszych trzech miesiącach ciąży, stres i stosowanie przez matkę używek podczas ciąży (kofeiny, nikotyny i alkoholu), niska masa urodzeniowa i komplika- 
cje w trakcie porodu (konieczność użycia kleszczy, owinięcie pępowiny wokół szyi, poród trwający ponad dobę, czy niedotlenienie dziecka [4, 6-9].

Współwystępowanie Zespołu Tourette'a z innymi zaburzeniami psychicznymi i zaburzeniami zachowania

Wyniki badań klinicznych i ustalenie epidemiologiczne sugerują, że jedynie ok. $10 \%$ pacjentów to przypadki „czystego zespołu Tourette'a”. U 90\% pacjentów rozpoznaje się zaburzenia współwystępujące, które w znaczącym stopniu wpływają na przebieg choroby i postępowanie terapeutyczne. Doniesienia te potwierdziły badania Robertson i wsp., w których odsetek pacjentów, u których nie rozpoznano zaburzeń współwystępujących wyniósł 13,5\% [10]. Szacuje się, że większość z 0,3-1\% dzieci w wieku szkolnym, które spełniają kryteria diagnostyczne TS zmaga się także z innymi zaburzeniami, m.in. z zespołem nadpobudliwości psychoruchowej z deficytem uwagi (ADHD), zaburzeniami obsesyjno-kompulsyjnymi (OCD), zaburzeniami afektywnymi, opozycyjno-buntowniczymi oraz innymi zaburzeniami zachowania $[10,11]$. Zaburzenia te pojawiają się w różnych etapach choroby, jednak ze względu na częstotliwość i intensywność tików mogą zostać przeoczone [12].

Wolańczyk i wsp. [13] wyróżniają:

- prosty zespół Tourette'a

- pełnoobjawowy zespół Tourette’a z koprolalią, kopropraksją, echolalią, echopraksją, palilalią, paliprakcją i dotykaniem obiektów wokół, a także

- zespół Tourette'a z objawami ADHD, OCD, samookaleczeniami i zaburzeniami snu.

W przypadku tej grupy pacjentów leczenie samych tików okazuje się niewystraczające. Mimo że tiki wraz z wiekiem mogą występować rzadziej, według niektórych badań problemy behawioralne utrzymują się, a nawet nasilają. Koncentracja na przebiegu i obrazie współistniejących z TS problemów wydaje się w procesie zdrowienia pacjentów kwestią kluczową, gdyż mogą one negatywnie wpływać na funkcjonowanie społeczne, relacje rówieśnicze oraz naukę [14]. Według Comings i Comings [15], w sytuacji występowania trudności w uczeniu się, deficytu uwagi lub problemów emocjonalnych u dzieci, należy przeprowadzić z rodzicami wywiad, dotyczący obecności tików ruchowych i wokalnych u dziecka i najbliższych członków rodziny.

\section{ZESPÓt NADPOBUDLIWOŚCI PSYCHORUCHOWEJ Z DEFICYTEM UWAGI}

Zespół nadpobudliwości psychoruchowej z deficytem uwagi (ADHD) należy do najczęściej rozpoznawanych zaburzeń behawioralnych u osób z zespołem Tourette'a. Już od 1973 roku zaczęto wnioskować, że wiele dzieci z TS bardzo często przejawia różnego rodzaju zaburzenia zachowania, określane minimalnymi zaburzeniami czynności mózgu, nadpobudliwością, czy zaburzeniami koncentracji. Szacuje się, że ADHD współwystępuje z TS u 25-90\% chorych (średnio u 60\%), a pierwsze objawy zaczynają być widoczne około 7. roku życia. Etiologia ADHD nie jest do końca poznana, a objawy ADHD występują u 2 do $15 \%$ dzieci. W początkowej fazie u chorych często obserwuje się niezgrabność, nadmierną aktywność, niską tolerancję na frustrację oraz „tendencję do wypadków” $[10,16,17]$. Przedstawione objawy kliniczne często poprzedzają początek tików [12]. U dzieci z TS i ADHD, poza nadruchliwością i impulsywnością, diagnozuje się także zaburzenia w zakresie funkcji poznawczych, w tym wykonawczych [16].

W wielu badaniach analizowano, czy objawy współwystępującego z TS ADHD różnią się od tych, które występują u pacjentów, u których nie ma tików oraz czy obecność symptomów ADHD lub nasilenie tików ma większy wpływ na funkcjonowanie osób z TS. Harcherik i wsp. [18] dokonali porównania między czterema grupami pacjentów: 1) z zespołem Tourette'a, 2) z ADHD, 3) z ADHD i padaczką oraz 4) grupą kontrolną, biorąc pod uwagę, m.in. funkcjonowanie poznawcze, małą i dużą motorykę, funkcje percepcyjno-ruchowe oraz wskaźniki neurologiczne. Pacjenci z TS uzyskali wyniki zbliżone do grupy kontrolnej (osób zdrowych), natomiast osoby z ADHD oraz ADHD i padaczką wypadły gorzej. Okazało się, że dzieci z ADHD i padaczką przejawiały trudności prawie w każdym obszarze. Zarówno te, jak i inne badania dowiodły, że w TS to objawy ADHD mają większy wpływ, niż tiki na problemy społeczne, edukacyjne i zaburzenia zachowania [10]. Dzieci z TS osiągają lepsze wyniki w zakresie, m.in. funkcji wykonawczych, od dzieci z TS i ADHD lub tylko z ADHD [19]. Współwystępowanie ADHD wpływa na osoby z TS pod kątem liczby symptomów i funkcjonowania w obszarze społecznym i poznawczym [20].

Dokładny związek między zespołem Tourette'a a ADHD jest złożony. Istnieją cztery hipotezy, które starają się wyjaśnić jego charakter. Po pierwsze, sugeruje się, że oba zaburzenia są ze sobą ,genetycznie spokrewnione", jednak ta hipoteza była wiele razy kwestionowana [17]. Po drugie, inne badania [21] mówią o tym, że istnieją dwa typy osób z TS i ADHD. W pierwszym typie ADHD występuje niezależnie od TS, natomiast $\mathrm{w}$ drugim - ADHD jest drugorzędne w stosunku do TS. Po trzecie, „czyste ADHD” oraz ADHD + TS różnią się pod kątem fenomenologicznym, a ich związek jest niejasny. Ostatecznie, pacjenci z TS mogą przejawiać trudności z koncentracją, uwagą i kontrolą impulsów, ale na poziomie podprogowym diagnozy ADHD w DSM. W taki wypadku częstość współwystępujących chorób zależy od tego, w którym miejscu ustalono punkt odcięcia dla ADHD. Trzy ostatnie możliwości mogą być ze sobą powiązane, jednak konieczne jest wykonanie większej liczby analiz [17].

\section{ZABURZENIA OBSESYJNO-KOMPULSYJNE}

Zaburzenia obsesyjno-kompulsyjne (OCD) charakteryzują się nawracającymi, uporczywymi myślami, nazywanymi obsesjami oraz kompulsjami, które przyjmują postać powtarzalnych i pozornie celowych zachowan, wykonywanych stereotypowo, bądź zgodnie z określonymi zasadami. Obsesje i kompulsje stanowią dla jednostki źródło niepokoju oraz mogą w znaczący sposób zakłócać jej społeczne funkcjonowanie [17].

Według Pauls i wsp. [22] OCD można podzielić na trzy typy. Pierwszy związany jest z występowaniem OCD i tików w rodzinie, drugi z występowaniem OCD w rodzinie, 
jednak bez obecności tików oraz trzeci, który przejawia się u osób, których wywiad rodzinny nie jest obciążony, ani OCD, ani tikami.

Zaburzenia obsesyjno-kompulsyjne są drugim najczęściej rozpoznawanym zaburzeniem współistniejącym z zespołem Tourette'a. W badaniach Ubhi i wsp. [23] odsetek pacjentów z współwystępującym OCD okazał się największy i wyniósł 31,1\%. Objawów obsesyjno-kompulsyjnych (OCS) może doświadczać od 50 do $80 \%$ pacjentów z TS [24]. Zaburzenia obsesyjno-kompulsyjne występują u osób z zespołem Tourette’a częściej, niż w populacji ogólnej i mogą nasilać się wraz z wiekiem [16]. Zwykle mają swój początek po 3-6 latach od pojawienia się tików i są zmienne w czasie. Większość pacjentów zgłasza objawy przemawiające za OCD dopiero w okresie późnego dzieciństwa lub wczesnym etapie dojrzewania. OCD mogą w znaczącym stopniu obciążać ogólny obraz kliniczny TS i utrzymywać się w wieku dorosłym, mimo okresów remisji. U ponad połowy, a nawet $2 / 3$ pacjentów z TS tiki występują rzadziej lub całkowicie zanikają w końcowym etapie okresu dojrzewania. W przypadku OCD istnieje duże prawdopodobieństwo utrzymywania się objawów, mimo ustępowania tików [6, 25].

Odróżnienie złożonych tików od objawów kompulsywnych (OCS) może być kwestią problematyczną. Między tikami a OCS istnieje wiele podobieństw - oba dotyczą mimowolnych/natrętnych powtarzalnych zachowań i mogą obejmować zjawiska sensoryczne (SP) [26]. Dostępne dane świadczą również o tym, że obu zaburzeniom towarzyszą patologiczne zmiany w obwodzie zwojów korowo-podstawnych (głównie w prążkowiu) [27].

Uważa się, że obraz OCD współwystępującego z TS różni się od jego „czystej” postaci. W przypadku pacjentów z TS obsesje dotyczą najczęściej seksualności, religii, agresji, czy potrzeby utrzymania symetrii, natomiast kompulsje przymusu powtarzania, sprawdzania, liczenia, dotykania i samookaleczania. W „,czystej” postaci OCD, obsesje dotyczą głównie potrzeby utrzymania czystości oraz lęku przed chorobami i wypadkami, natomiast kompulsje obszarów związanych ze sprzątaniem oraz zachowaniem czystości ciała $[16,17]$.

Objawy kliniczne zaburzeń obsesyjno-kompulsyjnych i zespołu Tourette’a wyraźnie się pokrywają, jednak mimo nakładających się wymiarów tych zaburzeń „czysta” postać OCD, OCD w zespole Tourette’a oraz zespół Tourette’a bez zaburzeń współwystępujących nie tworzą ciągłego spektrum [28].

\section{DEPRESJA}

Depresja może przybierać formę łagodnych lub głębszych zaburzeń nastroju. W najcięższych przypadkach ryzyko podjęcia próby samobójczej wynosi nawet $15 \%$. Etiologia zaburzenia jest złożona i uwzględnia zarówno czynniki genetyczne, jak i psychologiczne [17].

W zespole Tourette'a depresja może objawiać się w odmienny sposób - poprzez manifestowanie irytacji i złości. Wynika z trudności, które napotykają osoby z TS, a należą do nich: poczucie odmienności, brak kontroli nad własnym zachowaniem i impulsami oraz kłopoty $\mathrm{z}$ adaptacją do peł- nienia określonych ról społecznych [16]. Istotny wpływ na samopoczucie pacjentów ma także rodzaj farmakoterapii, mającej na celu redukcję tików. Ze względu na stygmatyzujący charakter TS, osoby chore mogą doświadczać izolacji społecznej i odrzucania w grupie rówieśniczej, co przyczynia się do obniżenia samooceny i nastroju [4]. Według Comings i Comings [29] depresja oraz objawy maniakalno-depresyjne stanowią integralną część zespołu Tourette'a, a nie jedynie objaw wtórny tików motorycznych i wokalnych.

Badania przeprowadzane wśród pacjentów z TS dowodzą, że ryzyko rozwoju depresji w tej grupie jest pięciokrotnie wyższe, niż wśród osób, u których nie występują tiki [30]. Według Robertson i wsp. [31], u 40\% badanych złe samopoczucie skutkowało zachowaniami autoagresywnymi. Okazało się, że podobnie jak w przypadku OCD, występowanie zaburzeń depresyjnych w TS może wynikać z obciążeń rodzinnych. Co ciekawe, badania Rizzo i wsp. wykluczyły związek między depresją a obsesyjnością [32].

Pacjenci z zespołem Tourette'a deklarują niższą jakość życia, która prawdopodobnie związana jest z różnymi aspektami choroby. Objawy depresyjne prowadzą do hospitalizacji pacjentów (ze względu na tendencje samobójcze). Biorąc pod uwagę stygmatyzujący charakter TS, ważnym aspektem wydaje się wprowadzanie programów profilaktycznych, których celem byłaby psychoedukacja społeczeństwa w obszarze TS $[4,33]$.

\section{ZABURZENIA ZACHOWANIA}

Zaburzenia zachowania (conduct disorder CD) charakteryzują się łamaniem norm społecznych i obejmują zachowania agresywne w stosunku do ludzi lub zwierząt, niszczenie mienia, oszustwa oraz kradzieże. W przypadku objawów „łagodniejszych” rozpoznawane są zaburzenia opozycyjno-buntownicze, przejawiające się, m.in. nieposłuszeństwem [10].

Badania Comings i Comings [34] dowiodły, że ważnym czynnikiem determinującym zaburzenia zachowania w zespole Tourette'a są zaburzenia uwagi. Wyniki świadczą również o wpływie na CD zaburzeń depresyjnych i OCD. Badania przeprowadzono wśród 246 pacjentów z TS, grupy kontrolnej składającej się z 47 osób, 17 pacjentów z zaburzeniami uwagi (ADD) oraz 15 pacjentów z ADD i tikami lub obciążeniem rodzinnym TS.

Według Robertson i wsp. [10] zaburzenia zachowania współwystępują z TS u 14,5 \% chorych, natomiast zachowania agresywne u 29.5\%. Ponadto, badania świadczą o występowaniu związku między zaburzeniami zachowania a ADHD. Podobne rezultaty uzyskali Sukhodolsky i wsp. [35] oraz Stephens i Sandor [36], co przemawia za hipotezą mówiącą o tym, że zachowania agresywne wiążą się nie z tikami, a z zaburzeniami współwystępującymi. Istnieją jednak doniesienia, które kwestionują ten pogląd [37].

Zachowaniami ściśle związanymi z zaburzeniami zachowania i ADD są zachowania społecznie nieodpowiednie (socially inappropriate behavior). W badaniach Kurlan i wsp. [38] prawie ponad $40 \%$ osób z TS przejawiało zachowania, które w mniejszym lub większym stopniu były krzywdzące dla innych i szkodliwe dla otoczenia. 


\section{ZACHOWANIA SAMOOKALECZAJĄCE}

Zachowania samookaleczające (self-injurious behaviour SIB) są objawem wielu zaburzeń neuropsychiatrycznych i definiuje się je jako świadome, powtarzające się dokonywanie obrażeń fizycznych na własnym ciele. SIB przejawia ok. $60 \%$ pacjentów z TS. Samookaleczenia mogą pojawiać się w formie kompulsywnego skubania skóry, bicia się, gryzienia ust i innych części ciała, piłowania zębów lub uderzania głową o przedmioty. Niewiele wiadomo o etiologii tego zjawiska, jednak w przypadku innych zaburzeń (np. ADHD) samookaleczenia wydają się mieć związek $\mathrm{z}$ trudnościami w kontroli impulsów. SIB mają prawdopodobnie na celu złagodzenie wewnętrznego napięcia podobnego do tego, które poprzedza złożone tiki lub zachowania kompulsywne. Badania dowodzą, że istnieje związek między samookaleczeniami a OCD, zaburzeniami nastroju oraz ADHD. Tendencje do samookaleczeń stanowią dla pacjentów źródło cierpienia i długotrwałych obrażeń fizycznych, a także wyzwanie terapeutyczne dla specjalistów $[37,39]$.

\section{POSUMOWANIE}

W niniejszym artykule nie opisano wszystkich zaburzeń współwystępujących z zespołem Tourette'a. W piśmiennictwie można znaleźć także informacje o współwystępowaniu TS, m.in. z zaburzeniami lękowymi, zaburzeniami osobowości, trudnościami w uczeniu się oraz autyzmem [17]. Ze względu na złożoność zespołu Tourette'a, diagnoza zaburzenia powinna być wielopoziomowa, a leczenie musi uwzględniać indywidualne funkcjonowanie jednostki. W przypadku oddziaływań psychologicznych, poza terapią poznawczo-behawioralną proponuje się również uczestnictwo w treningu autogennym, treningu asertywności, a także psychoedukację najbliższego środowiska [16].

\section{PIŚMIENNICTWO}

[1] Douglas W.W., Piacentini J., Walkup J.T.: Treating Tourette Syndrome and Tic Disorders: A Guide for Practicioners. The Guilford Press, New York 2007.

[2] Pużyński S., Wciórka J.: Klasyfikacja zaburzeń psychicznych i zaburzeń zachowania w ICD-10. Opisy kliniczne i wskazówki diagnostyczne. Uniwersyteckie Wydawnictwo Medyczne Vesalius, Kraków-Warszawa 2000.

[3] Hallett M.: Tourette Syndrome: Update. Brain Development 2015; 37: 651-655.

[4] Małek A., Golińska P.: Depresja w przebiegu zespołu Tourette'a. Psychiat. Pol. 2020; 54: 69-82.

[5] Piacentini J., Woods D.W., Scahill L., et al.: Behavior Therapy for Children With Tourette Disorder. A Randomized Controlled Trial. Journal of the American Medical Association 2010; 303: 1929-1937.

[6] Janik P., Wolańczyk T., Bryńska A., et al.: Postępowanie w tikach i zespole Gillesa de la Tourette'a - rekomendacje grupy ekspertów. Varia Medica 2018; 2: 527-545.

[7] Bagheri M.M., Kerbeshian J., Burd L., et al.: Recognition and Management of Tourette's Syndrome and Tic Disorders. American Family Physician 1999; 59: 2263-2272.

[8] Cavanna A.E., Servo S., Monaco F., et al.: The Behavioral Spectrum of Gilles de la Tourette Syndrome. The Journal of Neuropsychiatry and Clinical Neurosciences 2009; 21: 13-23.

[9] Czapiga A.: Dziecko z zepołem Tourette'a. [w:] Dzieci chore, niepełnosprawne i z utrudnieniami w rozwoju. Cytowska, B., Winczura, B., Stawarski, A. [red], Oficyna Wydawnicza Impuls, Kraków 2013.

[10] Robertson M.M., Cavanna A., Eapen V.: Gilles de la Tourette Syndrome and Disruptive Behavior Disorders: Prevalence, Associations, and
Explanation of the Relationships. The Journal of Neuropsychiatry and Clinical Neurosciences 2015; 27: 33-41.

[11] Bearpark J., Mujong D.P., Seri S., et al.: Headache in patients with Tourette syndrome: A systematic literature review. Cephalalgia Reports 2020; 3: 1-8.

[12] Zinner S.H.: Tourette syndrome - much more than tics. Contemporary Pediatrics 2004; 21: 22-36.

[13] Wolańczyk T., Stefanoff P., Komender J.: Zaburzenia tikowe. [w:] Postępy w diagnostyce leczeniu chorób układu nerwowego u dzieci. Jóźwiak S. [red.], BiFolium, Lublin 2000.

[14] Chang H.L., Liang H.Y., Wang H.S., et al.: Behavioral and Emotional Problems in Adolescents with Tourette Syndrome. Chang Gung Medical Journal 2008; 31: 145-152.

[15] Comings D.E., Comings B.G.: Tourette Syndrome: Clinical and Psychological Aspects of 250 Cases. American Journal of Human Genetics 1985; 37: 435-450.

[16] Milczarek 0., Starowicz A., Kwiatkowski S.: Zespół Gilles'a de la Tourette'a - wyzwanie dla medycyny i neuropsychologii. Specyfika diagnozy, charakterystyka neuropsychologiczna i możliwości terapii. Neuropsychiatria i Neuropsychologia 2011; 6: 142-150.

[17] Robertson M.M.: Tourette syndrome, associated conditions and the complexities of treatment. Brain 2000; 123: 425-462.

[18] Harcherik D.F., Carbonari C.F., Shaywitz S.E., et al.: Attentional and perceptual disturbances in children with Tourette's syndrome, attention deficit disorder, and epilepsy. Schizophrenia Bulletin 1982; 8: 356-359.

[19] Harris E.L., Schuercholz L.J., Singer H.S., et al.: Executive function in children with Tourette Syndrome and/or Attention Deficit Hyperactivity Disorder. Journal of the International Neuropsychological Society 1995; 6: 511-516.

[20] Brand N., Geenen R., Oudenhoven M., et al.: Brief Report: Cognitive Functioning in Children With Tourette's Syndrome With and Without Comorbid ADHD. Journal of Pediatric Psychology 2002; 27: 203-208.

[21] Pauls D.L., Leckman J.F., Cohen D.J.: Familial relationship between Gilles de la Tourette's syndrome, attention deficit disorder, learning disabilities, speech disorders, and stuttering. Journal of the American Academy of Child \& Adolescent Psychiatry 1993; 32: 1044-1050.

[22] Pauls D.L., Alsobrook J.P., Goodman W., et al.: A family study of obsessive-compulsive disorder. The American Journal of Psychiatry 1995; 152: 76-84.

[23] Ubhi M., Achnivu K., Seri S., et al.: Motor stereotypes in adult patients with Tourette syndrome. Future Neurology 2020, Address: https://doi. org/10.2217/fnl-2019-0031

[24] Bhirkram T., Crawley A., Ardold P., et al.: Examining the functional activity of different obsessive-compulsive symptom dimensions in Tourette syndrome. Neurolmage: Clinical 2020, Address: https://doi. org/10.1016/.jnicl.2020.102198

[25] Bloch M.H., Petersom B.S., Scahill L., et al.: Adulthood Outcome of Tic and Obsessive-Compulsive Symptom Severity in Children With Tourette Syndrome. Archives of Pediatrics and Adolescent Medicine 2006; 160: 65-69.

[26] Badenoch J., Cavanna A.E.: Pharmacotherapy for tics in adult patients with Tourette syndrome and other tic disorders. Neurological Sciences 2020, Address: https://doi.org/10.1007/s10072-020-04327-3

[27] Frick L., Pittenger Ch.: Microglial Dysregulation in OCD, Tourette Syndrome, and PANDAS. Journal of Immunology Research 2016, Address: http://dx.doi.org/10.1155/2016/8606057

[28] Swerdlow N.R., Zinner S., Farber R.H., et al.: Symptoms in ObsessiveCompulsive Disorder and Tourette Syndrome: A Spectrum? CNS Spectrums 1999; 4: 21-33.

[29] Comings B.G., Comings D.E. A Controlled Study of Tourette Syndrome. V. Depression and Mania. American Journal of Human Genetics 1987; 41: 804-821.

[30] Chou I.C., Lin H.C., Lin C.C., et al.: Tourette Syndrome and Risk of Depression: A Population-Based Cohort Study in Taiwan. Journal of Developmental \& Behavioral Pediatrics 2013; 34: 181-185.

[31] Robertson M.M., Banerjee S., Eapen V., et al.: Obsessive compulsive behaviour and depressive symptoms in young people with Tourette syndrome. European Child \& Adolescent Psychiatry 2002; 11: 261-265.

[32] Rizzo R., Gulisano M., Martino D., et al.: Gilles de la Tourette Syndrome, Depression, Depressive Illness, and Correlates in a Child and Adolescent Population. Journal of Child and Adolescent Psychopharmacology 2017; 27: 243-249.

[33] Robertson M.M.: Mood disorders and Gilles de la Tourette's syndrome: an update on prevalence, etiology, comorbidity, clinical associations, and implications. Journal of Psychosomatic Research 2006; 61: 349-358. 
[34] Comings D.E., Comings B.G.: A Controlled Study of Tourette Syndrome. II. Conduct. American Journal of Human Genetics 1987; 41: 742-760.

[35] Sukhodolsky D.G., Scahill L., Zhang H., et al.: Disruptive Behavior in Children With Tourette's Syndrome: Association With ADHD Comorbidity, Tic Severity, and Functional Impairment. Journal of the American Academy of Child \& Adolescent Psychiatry 2003; 42: 98-105.

[36] Stephens R.J., Sandor P.: Aggressive Behaviour in Children with Tourette Syndrome and Comorbid Attention-Deficit Hyperactivity Disorder and Obsessive-Compulsive Disorder. The Canadian Journal of Psychiatry 1999; 44: 1036-1042.
[37] Walkup J.T., Mink J.W., Hollenbeck P.T.: Tourette syndrome. Lippincott Williams \& Wilkins, Philadelphia 2006.

[38] Kurlan R., Daragjati Ch., Como P.G., et al.: Non-obscene Complex Socially Inappropriate Behavior in Tourette's Syndrome. Journal of Neuropsychiatry 1996; 8: 311-317.

[39] Mathews C.A., Waller J., Glidden D.V., et al.: Self injurious behaviour in Tourette syndrome: correlates with impulsivity and impulse control. Journal of Neurology, Neurosurgery and Psychiatry 2004; 75: 11491155. 